\title{
Contemporary conservation doctrine - issues of conservation protection zones based on the example of Tarnobrzeg
}

\author{
Marek Gosztyła ${ }^{1}$, Agata Mikrut $^{2, *}$ \\ ${ }^{1}$ Rzeszów Technical University, Monuments Conservation Department, al. PowstańcówWarszawy \\ 12, 35-959 Rzeszów, Poland \\ ${ }^{2}$ Rzeszów Technical University, Monuments Conservation Department, al. PowstańcówWarszawy \\ 12, 35-959 Rzeszów, Poland
}

\begin{abstract}
The paper concerns the issue of conservation protection covering the researched areas of Tarnobrzeg. In particular, it describes the principles of delimiting areas and grounds for narrowing the previously adopted preservation zones. Based on reliable analyses, one presents the fundamentals, which result in the necessity of modifying and verifying the protection zones. The reasons for such a proceeding arise from the continuous development of civilization. Together with this, it is necessary to update urban areas, which is why the conservation works protecting the historic urban fabric should not stand in the way of modern urban development. Present-day conservation doctrine cannot seek to inhibit the almost natural process of the transformation of urban structures. Doctrines should correspond with contemporary realities and create opportunities for the urban and architectural development of the urban space while respecting and exposing historic architecture. The rational application of conservation doctrines and undertaking activities in a substantive manner will allow the creation of multilayer city compositions that represent an architectural depiction of history. The described issue of conservation protection zones in Tarnobrzeg is to be a form of discussion on the application of applicable conservation doctrines in the reality of contemporary cities. The question, whether the objectives and methods of action arising from the adopted conservation theory fulfil their basic function today, seems to be one of the most important issues of contemporary conservation of monuments. Since there is no doubt that finally clarified conservation decisions, formulated without thorough analysis and research, may and do result in not always expected architectural solutions.
\end{abstract}

The Act of 23 July 2003 on the protection and care of monuments (Journal of Laws of 2003 No. 162 item 1568 as amended), obligates to designate conservation protection zones and conclude them along with arrangements in the study of conditions and directions of spatial development of the community and in the local spatial development plan. They

${ }^{*}$ Corresponding author: a.mikrut@prz.edu.pl 
include the detailed guidelines, orders and prohibitions as well as restrictions aimed at protecting monuments within this area. The determination of protection in the local spatial development plan, in addition to being entered into the register of monuments, recognition as a historical monument, and the creation of a cultural park constitutes one of the forms of monument protection within the meaning of art. 7 of the cited act [3]. Sometimes, the conservation protection zones, once defined, require the repeated analysis and verification. It was decided that such a verification be carried out within three zones covered by conservation protection in Tarnobrzeg.

As per the municipal monuments register card, urban layout within the historical spatial plan of Tarnobrzeg city was entered into the register of monuments on 04.06.1984 under the number 285/A. Subsequently, in 2017, conservation opinions were requested to provide grounds to reduce the protection zone by three areas in the city of Tarnobrzeg. The range of the existing conservation zone and areas proposed for exclusion is presented on the map (Fig.1) [6].

As E. Małachowicz reports, according to the analysis developed in 1975 by the team headed by K. Pawłowski, it is possible to designate the following protection zones of urban complexes for the purpose of protection and revitalization activities:

- Zone "A" - full conservation protection of valuable, historical spatial structure, which should be strictly preserved.

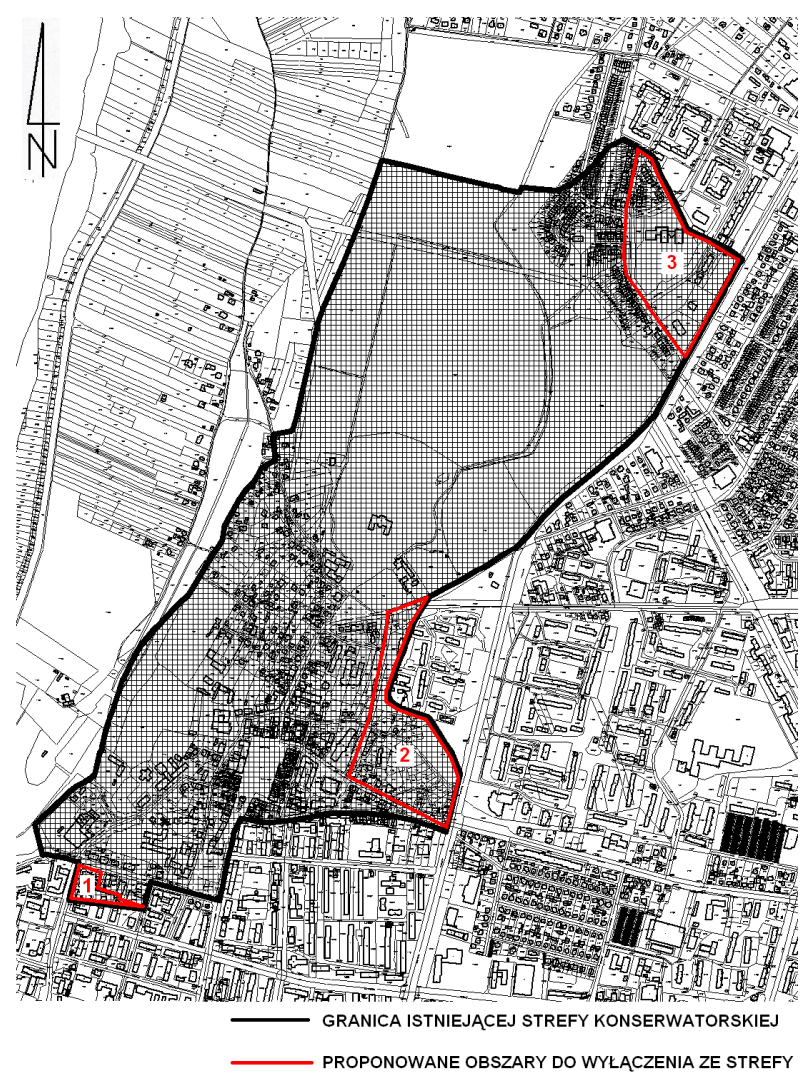

Fig. 1. Area of the existing conservation zone in Tarnobrzeg with three areas proposed for exclusion from the zone.

- Zone "B" - conservation protection of basic structures with cultural values and guidelines regarding the scale and character of the new architecture.

- Zone "E" - the so-called exposition area, where areas can be left without development or should have defined dimensions in order to expose historic buildings.

- Zone "K" - landscape protection, focusing on the integration of landscape with a historic complex.

- Zone "W" - archaeological protection, excluding from development the potential areas of archaeological exploration [4]. 
Of course, the designation of zones according to this classification itself depends on the rank and qualities of the city. The scopes and directions of the protection of historical complexes are subject to change due to the development of theory of conservation.

Preserving monuments that are a testimony of a bygone era lies in the interest of the community, which has also been written into the Act on the protection and care of monuments. Taking into account this interest, in particular the interest of a local community is one of the duties of public administration bodies, which clearly delimits the boundaries of protection zones. The final decision, taken by the administrative authorities, aimed at protecting the cultural heritage in spatial planning can only be made after collecting and considering every aspect of this issue. This decision is burdened with clerical and economic liability. It should be based on reliable facts, evidence and reasons for believing that other evidence is unreliable. Opinions about the multiplicity of conservation theories depending on the object, its location and time are voiced. However, only science should play a major role in the process of shaping the conservation theory. In conservation procedures, it is necessary to take into account the achievements of people who have permanently contributed to the development and art of the protection of monuments $[15,10]$. Marian Kornecki made the attempt of defining the boundary, to be crossed by neither an intervention nor the conservation arrangement. He also pointed out that the criteria, once set, would need verification and updating along with the progress of science and conservation methods. Bogusław Krasnowolski recalled the accomplishments of Mr. Kornecki in his lecture, attempting to present the problems of designing conservation protection zones. The author pointed out the importance of historical and landscape analyses in a broad spatial context as well as interdisciplinary and comprehensive research [2]. Multifaceted field studies and studies of conservation documentation can give the justification for considering and answering the question of intended verification of the conservation protection zone [10]. When conducting studies and an analysis of historical centres, it is important to define the boundaries of original layouts. The determination of contemporary city borders is also difficult. Knowledge of urban layouts planning is the first element in determining historical city complexes. In addition, one should analyse the interiors, assess the value of panoramic views and the values of architectural monuments that have been preserved [10, 4].

Opinions giving the potential grounds for reducing conservation protection zones in Tarnobrzeg were drawn up after the completion of field studies at specific sites aimed at drawing attention to urban planning and the architectonic matrix. Verification of the protection zones was possible after performing thorough analyses of the cultural values of a specific site, development physiognomy, the specifics of placement near existing buildings and the cultural image of the city [10].

Referring to the map, the area marked with the number ' 1 ' is the area with diversified development. This complex houses the objects that represent values from the period of historicism and secession such as the Tarnobrzeg Culture Centre complex (former seat of the Clerical Casino Society - Towarzystwo Kasynowo Urzędnicze) and the object after the former edifice of the "Sokół" Gymnastic Society (Wisła cinema). In addition, it also houses buildings constructed in the second half of the 20th century, descended from modernist trends, and built in accordance with the design principles of that time. The number of these buildings gives an impression of a modern architectural and urban complex. Objects that draw inspiration from neighbouring buildings have been built within this zone, façades of which repeat rhythmic steps, which can be classified as an environmental architecture. Within the same area, contrasting buildings have also been built, a characteristic example of which is a housing estate and public utility buildings designed in accordance with modernist ideas, hence as simple and monotonous blocks [9]. 


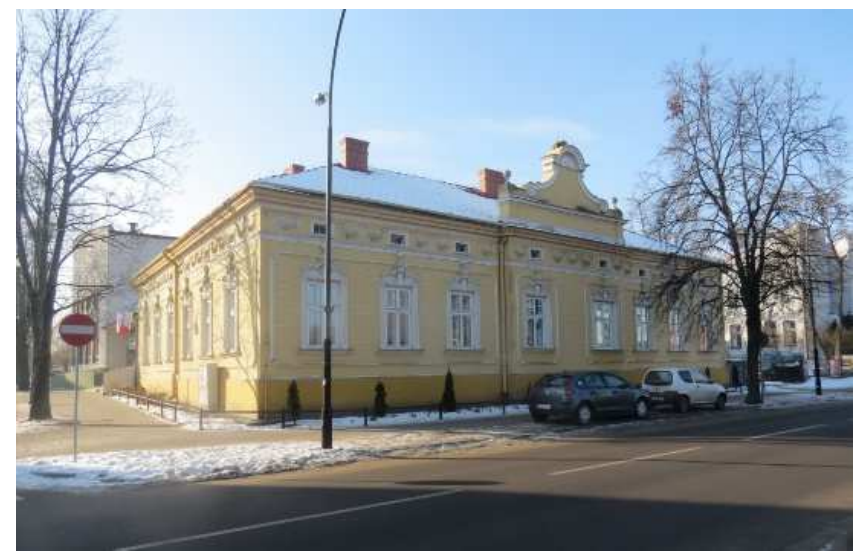

Fig. 2. Facade of an object from the historicism era at ul. Sokoła (area no. 1), photo by M. Gosztyła.

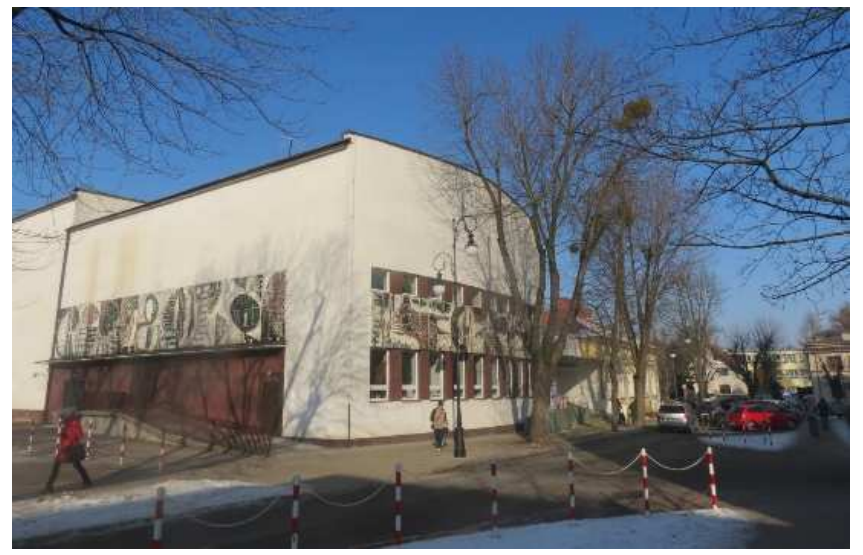

Fig. 3. Successful combination of contemporary architecture with an object from the historical period, view from ul. J. Słowackiego (area no. 1), photo by M. Gosztyła.

Bogusław Szmygin, in his paper titled "Contemporary conservation doctrine - present status and development outlooks" points out that the principles of conservation protection written in traditional doctrinal documents, such as the Venetian Charter, should be elaborated once again. Objectives that were formulated in doctrines more than half a century ago require updating and conservation activity methods should be developed once again. Applying the existing conservation principles to all objects recognized as monuments can lead to an undesirable effect [3].

It is unacceptable to follow an allegation in professional conservation activities. Therefore, the area numbered '2,' at ul. Dominikańska, where the layout with historical traits has become obliterated and blurred, cannot be covered by strict conservation protection, i.e. zone "A". The spatial analysis between the streets: Wyszyńskiego, Sienkiewicza and Dominikańska has demonstrated the disharmony of development, where the strongest point is the several-storey edifice of the District Court. Its over-scaled height disrupted the proportions of buildings at the market square, because of which the most critical historical values have been lost. The city has not protected itself from the loss of panoramic views and obscuring the historical buildings of the market square [13]. The analysis of the area numbered '2,' to be excluded from the conservation zone in Tarnobrzeg, proved that this area 
is not a carrier of historical memory. Architectonic objects were created in line with the future, new functional and spatial programs, and therefore there is no justification for recreation of an architecture that does not exist. Retroversion, recomposition in architecture does not find any convincing arguments. Neither the architecture of buildings nor their scale create a well thought-out spatial concept, on the contrary - they introduce within this area the so-called architectonic chaos [10].

There are plenty of examples of buildings from the second half of the 20th century in the centre of Tarnobrzeg, which represent the so-called architecture of pastiche. The visage of the city can be changed by a modern architecture designed in its vicinity. The exclusion of area number ' 2 ' from the protection zone and using this area for the purpose of modern spatial design will result in an emergence of a strong accent for a centre that is being developed. These arguments provide the basis for the exclusion of this area from conservation protection [10].

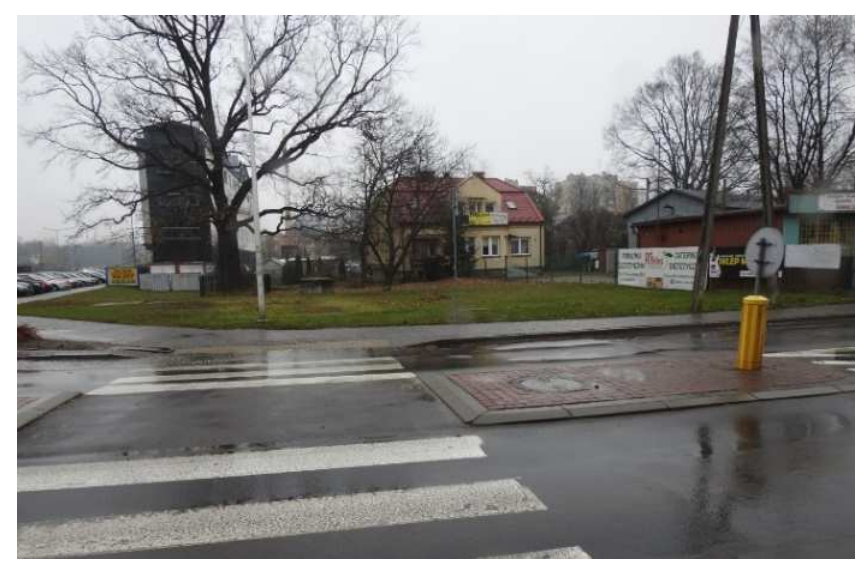

Fig. 4. View towards the north of buildings on ul. kardynała St. Wyszyńskiego and ul. H. Sienkiewicza, noticeable architectural chaos (area no. 2), photo by M. Gosztyła.

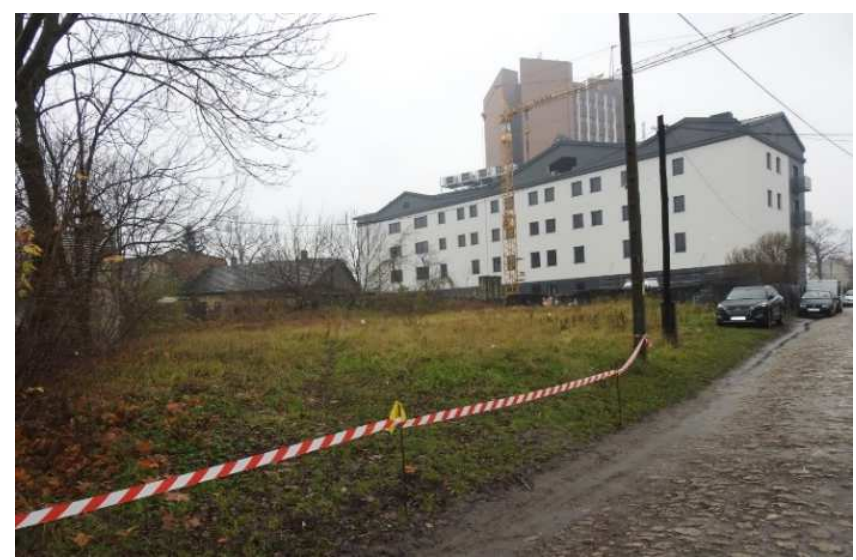

Fig. 5. View towards the southwest on a fragment of neglected buildings and a new hotel from the side of ul. Dominikańska (area no. 2), photo by M. Gosztyła.

The city should be a vivid, developing organism and not a historical open-air museum. The constant development of civilization inevitably enforces changes in the spatial development plan [4].Therefore, it is necessary to design new objects that follow modern 
trends in degraded urban quarters as well as in the area covered by conservation protection. Objects with modern architecture should respect the values of historic urban complexes. Such an approach is a reflection of modern conservation thought. Contemporary architecture may constitute a contrast to existing buildings, but it can also be inspired by the history of a specific place. Present-day designing requires a broad look from the perspective of the composition of cultural landscapes. By way of introducing modern architecture, a solution can be adopted that will take into account the existing over-scaled development, and consequently, will affect the exposition of preserved cultural values, thus highlighting the architectural values of buildings representing the previous style periods. The history of a place will be expressed in a new spatial composition. Buildings with contemporary forms appropriately adapted to the historic surroundings, and the creation of new interiors and views is justified and leads to the restitution of cultural values $[13,4]$. Art. 10 of the International Charter for the Protection of Historical Cities includes a provision drawing attention to the fact that "introduction of elements of contemporary nature may contribute to the enrichment of a complex provided they do not harm the harmonious entirety of its development". The same chapter in art. 5 includes the arrangements regarding the creation of a protection plan, which "should highlight and harmoniously link the historic district with the entire city" [5]. International recommendations included in the Krakow 2000 Charter, regarding the creation of a conservation design for a historic city or village, indicate the needs of the planning and management of anticipated changes and the possibility of verification of selected solutions. The issue of preserving the cultural heritage requires integration with social and economic aspects [7].

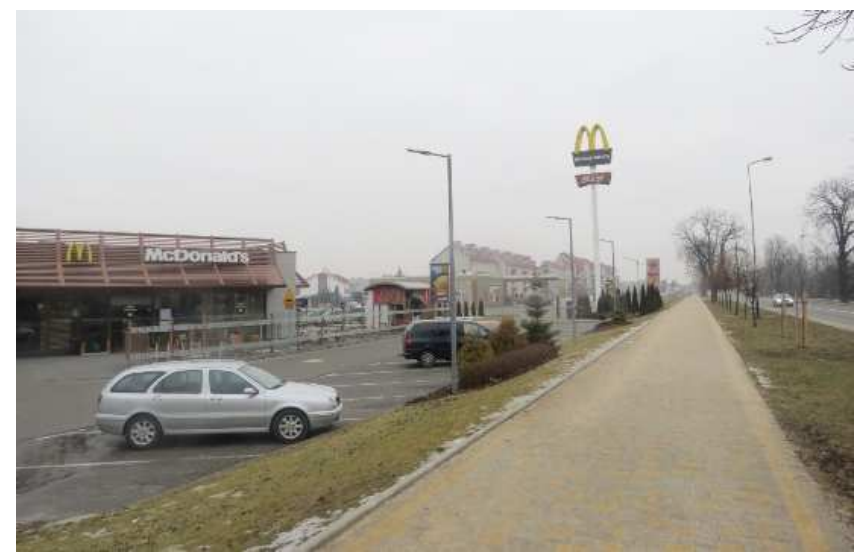

Fig. 6. View towards the northeast on the development of the area between ul. Wł. Sikorskiego and ul. Wiejska (Area no. 3), a fragment of the Dzików housing district, photo by M. Gosztyła.

Buildings with a new architectural expression characterize the area numbered ' 3 ' of Tarnobrzeg, and marked on the map. Contemporary residential buildings in this quarter and public utility objects, i.e.: McDonalds, Lotos fuel station, and Primary School No. 9, meet functional standards, but they do not represent environmental values. These objects present the type of architecture commonly found in various places in the country [11]. Entry into the register of monuments does not imply a prohibition on the implementation of modern architecture within an area covered by conservation protection. Taking into account the protection principles in spatial planning and development, pursuant to the Act, provide the public administration bodies with tools for protective measures combined with the revitalization and development of cities. Devastated and disordered landscape of the city should be subject to a process of revitalization bearing in mind the creation of a future landscape [13]. 
Discussions held around the modern conservation doctrine are aimed at searching for a compromise between preserving and respecting the architectural heritage, the contemporary requirements of life, new architectonic trends, modern technologies and the laws of economics [10]. While assessing the areas covered by the protection zone, it is necessary to carry out analyses of the preserved cultural values of the place, character and form of development, and the specifics of the location. Furthermore, a reliable analysis of the existing structures of development near the studied area and an analysis of the contemporary physiognomy of the location can determine the arguments for maintaining or excluding the area from the conservation protection zone.

Sociological and architectural studies, not the zones, will set the directions for city development. Not the administration, but the designer along with local community will create a model of the contemporary urban organism [10]. The protection of the cultural environment is the never-ending activity of the architect-conservator. Deliberation regarding the issue of formation and verification of protection zones in the light of modern conservation doctrine can be concluded by recalling Mieczysław Porębski's comment cited in the publication of A. Kadłuczko, that a space is not given to us once and for all but "constructed and reconstructed again and again as new and always differently" [1].

\section{References}

1. A. Kadłuczka, Ochrona zabytków architektury, 1 (SKZ, Kraków, 2000)

2. B. Krasnowolski, Doktryny konserwatorskie a doświadczenia Społecznego Komitetu Odnowy Zabytków Krakowa [w:] Doktryny i realizacje konserwatorskie $w$ świetle doświadczeń krakowskich ostatnich 30 lat, 415-427 (WAM, Kraków, 2011)

3. B. Szmygin, Współczesna doktryna konserwatorska-stan obecny i prognozy rozwoju [w:] Doktryny i realizacje konserwatorskie w świetle doświadczeń krakowskich ostatnich 30 lat, 105-116 (WAM, Kraków, 2011)

4. E. Małachowicz, Konserwacja i rewaloryzacja architektury w środowisku kulturowym (PWR, Wrocław, 2007)

5. Międzynarodowa Karta Ochrony Miast Historycznych ICOMOS, Toledo/Waszyngton 1987, Vademecum Konserwatora Zabytków, 91-94 (PKN ICOMOS, Warszawa, 1996)

6. Karta Gminnej Ewidencji Zabytków 1/2132, WUOZ (Przemyśl, 01.04.2010)

7. Karta Krakowska 2000..., Vademecum Konserwatora Zabytków, 135-138 (PKN ICOMOS, Warszawa, 2015)

8. M. Gosztyła, Opinia konserwatorska „,Analizy wartości zabytkowej obszary położonego przy ul. Dominikańskiej, ograniczonego od wschodu ul. Sikorskiego, od potudnia ul. Sienkiewicza, od zachodu ul. Wyszyńskiego, od pólnocy zabudowa wielorodzinna przy ul. Sikorskiego" (Rzeszów, 28.11.2016)

9. M. Gosztyła, Opinia konserwatorska dająca podstawy do zmniejszenia strefy ochrony konserwatorskiej o obszar nr 1 na terenie miasta Tarnobrzega (Rzeszów, 21.02.2017)

10. M. Gosztyła, Opinia konserwatorska dajaca podstawy do zmniejszenia strefy ochrony konserwatorskiej o obszar nr 2 na terenie miasta Tarnobrzega (Rzeszów, 21.01.2017)

11. M. Gosztyła, Opinia konserwatorska dajaca podstawy do zmniejszenia strefy ochrony konserwatorskiej o obszar nr 3 na terenie miasta Tarnobrzega (Rzeszów, 21.02.2017)

12. M. Gosztyła, Opinia $w$ sprawie zmiany granic strefy konserwatorskiej $w$ oparciu o najnowsza doktrynę, dająca podstawy do zmniejszenia strefy ochrony konserwatorskiej o obszar nr 2 na terenie miasta Tarnobrzega (Rzeszów, 28.11.2017) 
13. M. Gosztyła, Recenzja do opinii „,Wojewódzkiego Urzędu Ochrony Zabytków w sprawie zaopiniowania projektu do studium uwarunkowań $i$ kierunków zagospodarowania przestrzennego miasta” (Rzeszów, 10.06.2017)

14. Karta Wenecka, Wenecja 1964, Vademecum Konserwatora Zabytków, 41-44 (PKN ICOMOS, Warszawa, 2015)

15. Journal of Laws of 2003, No. 162, item 1568, as amended, Ustawa z dnia 23 lipca 2003 r. o ochronie zabytków i opiece nad zabytkami

16. K. Zeidler, O znaczeniu i roli teorii konserwatorskiej w procesie stosowania prawa, [w:] Współczesne problemy teorii konserwatorskiej w Polsce, 173-180 (WPL, WarszawaLublin, 2008) 